\title{
Faktor-Faktor yang Mempengaruhi Pendapatan Nelayan di Kabupaten Tanjung Timur
}

\author{
Muhammad Amali \\ Fakultas Ekonomi Universitas Batanghari \\ Correspondence email: m.amali278791@gmail.com
}

\begin{abstract}
This study aims to find out how much the factors that influence the income of traditional fishermen in Tanjung Jabung Barat Regency. This research was conducted in the fishing village of tungkal ilir sub-district, tanjung jabung barat district. This study uses primary data obtained by distributing questionnaires. The analytical tool used in this study is multiple linear regression. From the results of the simultaneous analysis ( $F$ test) that the variables of capital, technology, work experience and distance to sea together have an influence on the income of traditional fishermen in West Tanjung Jabung Regency. And from the results of a partial analysis ( $t$ test) that that capital has a positive and significant effect on the income of fishermen in the regency of tanjung jabung barat. Whereas technology and distance traveled to sea have a negative but not significant effect on the income of traditional fishermen in tanjung jabung barat district. And work experience has a positive but not significant effect on the income of traditional fishermen in the tanjung jabung barat district.
\end{abstract}

Keywords: Fishermen's Income, Capital, Technology, Work Experience and Traveling Mileage

\section{Pendahuluan}

Perikanan seharusnya menjadi sektor yang paling unggul di Indonesia karena kondisi geografis Indonesia yang merupakan negara kepulauan memiliki kelimpahan sumberdaya perikanan tangkap yang sangat besar. Kekayaan alam yang melimpah pada sektor sumberdaya laut lazimnya memberikan dampak yang positif bagi masyarakat pinggiran laut khususnya yang berprofesi sebagai nelayan.Sumberdaya perikanan secara potensial dapat dimanfaatkan untuk meningkatkan taraf hidup dan kesejahteraan nelayan, namun kenyataanya masih cukup banyak nelayan yang berada pada kondisi ekonomi yang kurang baik kerena tidak dapat meningkatkan hasil tangkapannya, sehingga pendapatan mereka pun tidak meningkat.

Tingkat kesejahteraan nelayan sangat dipengaruhi oleh hasil tangkapannya.Jika hasil tangkapannya bagus, maka pendapatan mereka juga baik, begitu pula sebaliknya.Selain itu, beberapa faktor yang mempengaruhi pendapatan nelayan menurut Sujarno (2008) meliputi faktor sosial dan ekonomi yang terdiri dari besarnya biaya, jumlah perahu, jumlah tenaga kerja, jarak tempuh dan pengalaman. Beberapa masalah perikanan tangkap yang juga mempengaruhi pendapatan yang diperoleh nelayan menurut Murdiyarto (2007) adalah tingginya harga bahan bakar, sumberdaya yang terkuras dan harga ikan sebagai output dalam perikanan tangkap.

Dalam upaya wujud peningkatan kesejahteraan nelayan dan mendukung otonomi daerah diperlukan langkah strategi pembangunan sektor perikanan dan kelautan yang mengarah terhadap peningkatan produktivitas perikanan yang berimplikasi terhadap kesejahteraan nelayan.Dalam peningkatan kesejahteraan masyarakat dapat dilakukan apabila pendapatan masyarakat mengalami peningkatan yang cukup hingga mampu memenuhi kebutuhan dasar untuk kehidupannya.Dapat diartikan bahwa kebutuhan-kebutuhan pangan, sandang, perumahan, kesehatan, keamanan dan sebagainya tersedia dan mudah dijangkau untuk masyarakat sehingga masyarakat miskin semakin sedikit. Para nelayan melakukan pekerjaannya dengan tujuan untuk memperoleh pendapatan demi kebutuhan hidup.Untuk pelaksanaannya diperlukan beberapa perlengkapan dan dipengaruhi pula oleh banyak faktor guna mendukung keberhasilan kegiatan.

Masyarakat yang mempunyai mata pencaharian dan berpenghasilan sebagai nelayan merupakan salah satu dari masyarakat yang melakukan aktivitas usaha dengan mendapat penghasilan bersumber dari kegiatan nelayan itu sendiri.Nelayan adalah orang yang secara aktif melakukan pekerjaan dalam operasi penangkapan ikan dan binatang air lainnya.Tingkat kesejahteraan nelayan sangat ditentukan oleh hasil tangkapannya.Banyaknya tangkapan tercermin pula besarnya pendapatan yang diterima dan pendapatan tersebut sebagian besar untuk keperluan konsumsi keluarga.Dengan demikian tingkat pemenuhan kebutuhan konsumsi keluarga atau kebutuhan fisik minimum (KFM) sangat ditentukan oleh pendapatan yang diterima. Masyarakat yang berada di kawasan pesisir memiliki mata pencaharian utama sebagai nelayan. Sektor perikanan memberikan kontribusi dalam peningkatan kesejahteraan nelayan.Dalam hal ini perikanan sebgai salah satu SDA (Sumber Daya Alam) yang mempunyai peranan penting dan strategis dalam pembangunan perekonomian nasional terutama dalam meningkatkan perluasan kesempatan kerja di sektor perikanan.Sumber daya perikanan secara potensial dapat dimanfaatkan untuk meningkatkan taraf hidup masyarakat nelayan, namun pada kenyataannya masih cukup banyak neyalan yang belum dapat meningkatkan hasil tangkapannya, sehingga tingkat pendapatan nelayan tidak meningkat. 
Dengan adanya modal kerja maka usaha nelayan dalam melaut untuk menangkap ikan dan kemudian menghasilkan jumlah ikan tangkapannya.Makin besar modal kerja maka makin besar pula peluang hasil tangkapan yang diperoleh.Dalam hal ini dapat terlihat ketersediaan modal kerja yang dimiliki nelayan berupa asset atau modal yang dimiliki oleh nelayan seperti harga beli kapal dan modal dalam aktivitas sekali melaut (umpan, es balok, bahan bakar yang digunakan dan makanan/minuman pekerja). Kemajuan teknologi dalam bidang penangkapan ikan yang semakin berkembang memberikan dampak positif terhadap peningkatan permintaan pasar.Perkembangan usaha perikanan tangkap dapat dilihat berdasarkan perkembangan konstruksi dan rancangan alat penangkapan, semakin majunya teknologi yang digunakan dalam penangkapan ikan dapat meningkatkan pendapatan nelaya. Kegiatan penangkapan ikan di Kabupaten Tanjung Jabung Barat menggunkan perahu/kapal yang sering digunakan oleh nelayan untuk menangkap ikan di laut. Untuk jenis-jenis kapal yang sering digunakan untuk penangkapan ikan bisa terdiri dari kapal gillnet dan kapal trawl. Kapal Gillnet merupakan kapal yang mengoperasikan alat tangkap jaring insang (gill net) termasuk trammel net. Gillnet disebut juga jaring insang karena alat tangkap ini dibuat dan dirancang secara khusus agar ikan yang kita tangkap terkena melalui insang ikan makanya alat tangkap gilnet ini sama dengan alat tangkap yang sifatnya menjerat ikan melalui insang. Alat tangkap Gillnet atau jaring insang ini banyak digunakan oleh para nelayan tradisional maupun nelayan modern dikarenakan alat ini sangat praktis untuk menangkap ikan juga ramah terhadap lingkungan. Kapal Trawl merupakan kapal yang menggunakan trawl (pukat hela) sebagai alat tangkapnya dan mempunyai mesin dengan tenaga yang sesuai untuk menarik pukat dengan kecepatan yang memadai. Jenis kapal penangkap Trawl biasanya di peruntukkan untuk menangkap udang. Kapal trawl membutuhkan tenaga kapal yang sangat besar. Karena tenaga tersebut di gunakan untuk menarik atau meng hela jaring trawl istilah dalam penangkan ikan adalah Towing.

Menurut Mashyuri dalam Sujarno (2008) Jarak tempuh yang semakin jauh akan mempunyai lebih banyak kemungkinan memperoleh hasil tangkapan (produksi) yang lebih banyak dan tentu memberikan pendapatan yang lebih besar di bandingkan penangkapan dekat pantai, Jarak tempuh melaut nelayan dalam menangkap ikan, Semakin jauh nelayan dalam melaut maka ikan yang bisa ditangkap akan semakin banyak dan nilai ikan dipasarpun makin besar. Namun bila jarak tempuh melaut nelayan hanya di pesisir pantai, maka ikan yang bisa ditangkap hanya sedikit dan nilai jual ikan di pasarpun akan tergolong rendah. Pengetahuan tentang teknik penangkapan hasil laut umumnya diperoleh secara turun menurun dari orang tua atau pendahulu mereka berdasarkan pengalaman. Dengan pertambahan usia, selalu akan diikuti oleh meningkatnya pengalaman kerja yang ditekuni. Akibat bertambahnya pengalaman di dalam mengerjakan suatu pekerjaan atau memproduksikan suatu barang, dapat menurunkan rata-rata ongkos per satuan barang. Sehingga semakin tinggi pengalaman seorang nelayan diasumsikan bahwa semakin efisien dan efektif dalam proses penangkapan hasil laut sehingga dapat meningkatkan pendapatan nelayan.

Armada perikanan adalah sekelompok kapal-kapal yang akan melakukan kegiatan penangkapan ikan di suatu daerah perairan (fishing ground). Armada penangkapan terdiri dari beberapa unit penangkapan ikan yang terdiri dari kapal, alat tangkap dan nelayan. Undang-undang Nomor 31 Tahun 2004 tentang Perikanan, mendefinisikan kapal perikanan adalah kapal, perahu atau alat apung lain yang digunakan untuk melakukan penagkapan ikan, mendukung operasi penangkapan ikan, pengelolaan ikan, pelatihan perikaan, dan penelitian atau eksplorasi perikanan. Untuk memberdayakan alat tangkap, beberapa jenis armada penangkapan dengan berbagai ukuran menempati wilayah penangkapan di pantai timur sumatera. Armada penangkapan yang digunakan pada umumnya didominasi oleh kapal berukuran kecil seperti perahu tanpa motor dan kapal motor yang berukuran di bawah 5 GT.

Tujuan dalam penelitian ini adalah untuk mengetahui mengetahui Faktor apa saja yang mempengaruhi pendapatan nelayan tradisional di kabupaten tanjung jabung barat, Untuk mengetahui pengaruh modal, teknologi, pengalaman kerja, dan jarak tempuh melaut secara simultan terhadap pendapatan nelayan tradisional di kabupaten tanjung jabung barat, Untuk mengetahui pengaruh modal, teknologi, pengalaman kerja, dan jarak tempuh melaut secara parsial terhadap pendapatan nelayan tradisional di kabupaten tanjung jabung barat.

\section{Landasan Teoritis Pendapatan}

Pendapatan nelayan adalah selisih antara total penerimaan (TR) dan semua biaya (TC). Jadi Pd $=$ TR-TC. Penerimaan usaha nelayan (TR) adalah perkalian antara produksi yang diperoleh (Y) dengan harga jual (Py). Biaya usaha nelayan biasanya diklasifikasikan menjadi dua yaitu biaya tetap (fixed cost) dan biaya tidak tetap (variable cost). Biaya tetap (FC) adalah biaya yang relatif tetap jumlahnya dan terus dikeluarkan walaupun produksi yang diperoleh banyak atau sedikit. Biaya variable (VC) adalah biaya yang besar kecilnya dipengaruhi oleh produksi yang diperoleh, contoh biaya untuk tenaga kerja. Total biaya (TC) adalah jumlah dari biaya tetap (FC) dan biaya variable (VC), maka TC = FC+VC, (Soekartawi, 2001). Pendapatan yang diterima oleh masyarakat nelayan digunakan untuk memenuhi segala kebutuhan konsumen dalam setiap rumah tangga mereka, misalnya membeli perlengkapan rumah tangga, membayar listrik bulanan, membayar bunga atas pinjaman atau utang lainnya, membeli sarana dan prasarana penangkapan ikan, biaya untuk melaut seperti (seperti bensi, es balok, rokok, dll) dan bahkan digunakan untuk biaya 
pendidikan anak-anak mereka. Pendapatan merupakan suatu hal yang sangat penting dalam menentukan laba atau rugi dari suatu usaha, laba atau rugi tersebut dipeoleh dengan melakukan pebandingan antara pendapatan dengan beban atau biaya yang dikeluarkan atas pendapatan tersebut. Pendapatan dapat di gunakan sebagai ukuran dalam menilai keberhasilan suatu usaha dan juga faktor yang menentukan dalam kelangsugan suatu usah. Pendapatan dapat diartikan sebagai jumlah uang yang dterima oleh seseorang atau badan usaha selama jangka waktu tertentu.

\section{Modal}

Modal merupakan salah satu faktor yang sangat penting dalam memulai suatu usaha. Dalam teori HarrodDomar mengenai fungsi produksi yaitu sejumlah modal yang dapat menciptakan suatu tingkat output tertentu dalam suatu kegiatan produksi dan untuk setiap kegiatan ekonomi akan dapat menyisihkan pendapatan. Modal kerja merupakan kemampuan ekonomis dari suatu masyarakat atau suatu kegiatan dalam memenuhi kebutuhan masyarakat dan menutupi biaya-biaya yang terjadi selama proses produksi. Modal menjadi salah satu faktor-faktor yang mempengaruhi tingkat pendapatan nelayan, nilai asset yang bergerak dalam satu unit penangkapan disebut juga sebagai modal. Pada umumnya, untuk satu jenis unit penangkap modal yaitu terdiri dari: alat-alat penangkapan (pukat dan lain-lain), sampan penangkap, alat-alat pengolah atau pengawet didalam kapal dan alat-alat pengangkutan laut yang dibutuhkan ketika nelayan pergi melaut (Mulyadi, 2007). Sebagaian dari modal yang dimiliki oleh nelayan digunakan sebagai biaya produksi atau biaya operasi, yaitu penyediaan input produksi (sarana produksi), biaya opersi dan biaya-biaya lainnya dalam suatu kegiatan nelayan. Biaya produksi atau biaya operasi nelayan biasanya diperoleh dari kelompok nelayan kaya ataupun pemilik modal (toke), karena adanya hubungan pinjam meminjam uang sebagai modal kerja dimana pada musim panen, hasil tangkap (produksi) ikan nelayan digunakan untuk membayar seluruh pinjaman uang, dan tingkat harga ikan biasanya ditentukan oleh pemilik modal.

Biaya total (total cost) sama dengan biaya tetap ditambah biaya variabel. Biaya tetap (fixed cost) adalah biaya yang besarnya tidak tergantung pada jumlah produksi. Biaya variabel (variable cost) adalah biaya yang besarnya tergantung pada tingkat produksi. Biaya rata-rata adalah biaya yang harus dikeluarkan untuk memproduksi satu unit output. Besarnya biaya rata-rata adalah biaya total dibagi jumlah output. Karena $\mathrm{TC}=\mathrm{FC}+\mathrm{VC}$, maka biaya rata-rata (average cost) sama dengan biaya tetap rata-rata (average fixed cost) ditambah biaya variabel rata-rata (average variable cost).

\section{Teknologi}

Kemajuan teknologi terjadi karena ditemukan cara baru atau perbaikan atas cara-cara lama dalam menangani pekerjaan-pekerjaan tradisional dan merupakan hasil temuan manusia. Teknologi yaitu cara melakukan sesuatu untuk memenuhi kebutuhan manusia dengan bantuan alat dan akal, sehingga memperkuat atau membuat lebih ampuh anggota tubuh, panca indera dan otak manusia. Dilihat dari teknologi peralatan tangkap yang digunakan oleh nelayan dapat dibedakan dalam dua katagori, yaitu usaha nelayan modern dan usaha nelayan tradisional. Usaha nelayan modern menggunakan teknologi penangkapan yang canggih dibandingkan dengan usaha tradisional. Nelayan dikategorikan sebagai seseorang yang pekerjaannya menangkap ikan dengan menggunakan alat tangkap yang sederhana, mulai dari pancing, jala, jaring, pukat, dan lain sebagainya. Namun dalam perkembanganannya dikategorikan sebagai seorang yang berprofesi menangkap ikan dengan alat yang lebih modern ialah kapal ikan dengan alat tangkap modern.

Semakin canggih teknologi yang digunakan nelayan maka akan semakin meningkatkan produktifitas hasilnya lebih meningkatkan produksi, yang didalamnya tersirat kesimpulan bahwa masyarakat akan memperoleh penghasilan yang lebih tinggi.

\section{Pengalaman Kerja}

Pengalaman sebagai nelayan untuk menggunakan secara langsung maupun tidak langsung, memberikan pengaruh kepada hasil tangkapan ikan, semakin besar hasil dari penangkapan ikan dan pendapatan yang diperoleh. Akibat bertambahnya pengalaman didalam mengerjakan suatu pekerjaan atau memproduksikan suatu barang dapat menurunan rata-rata ongkos persatuan barang. Hal ini adalah logis karena dengan bertambahnya pengalaman seseorang didalam mengerjakan pekerjaan itu, tentu saja akan di peroleh pelajaran untuk melakukannya dengan lebih baik serta lebih efisien. Suatu aspek yang menjadi akar kemiskinan nelayan adalah rendahnya pengalaman kerja. Dengan demikian, kurangnya pengalaman berdampak pada pemahaman proses penangkapan dan pemanfaatan hasil tangkapan. Banyak sekali nelayan yang mengambil jalan pintas untuk mendapatkan hasil yang lebih besar seperti menggunakan bom ikan atau racun. Para nelayan tidak pernah memikirkan dampak dimasa depan yang dapat terjadi bahwa ikan yang di bom atau racun secara alamiah akan merusak ekosistem laut yang berakibat pada hilangnya bibitbibit ikan. 


\section{Jarak Tempuh Melaut}

Jauh dekatnya daerah tangkapan dan besa kecilnya perahu yang digunakan menentukan lamanya waktu melaut. Pada umumnya penangkapan ikan lepas pantai yang dilakukan dalam waktu yang lebih lama dan lebih jauh dari daeah sasaran tangkapan ikan mempunyai lebih banyak kemungkinan memperoleh hasil tangkapan yang lebih banyak dan tentu memberikan pendapatan lebih besar dibandingkan dengan penangkapan ikan dekat pantai. Faktor jarak tempuh yang dilalui nelayan ketika melaut merupakan salah satu faktor yang mempengaruhi tingkat pendapatan karena apabila jarak tempuh yang semakin jauh maka kemungkinan untuk mendapatkan hasil (produksi) akan semakin meningkat atau akan lebih banyak sehingga memberikan pendapatan yang lebih besar dibandingkan penangkapan yang dilakukan didekat pantai. Jarak tempuh yang jauh membutuhkan waktu yang lama untuk sampai ke lokasi penangkapan ikan, sehingga bisa mendapatkan hasil tangkapan yang banyak dan menyebabkan tingkat pendapatan nelayan juga meningkat.Sehingga dapat dikatakan bahwa jarak tempuh yang jauh akan berpengaruh terhadap tingkat pendapatan nelayan. (Dahuri, 2004).

\section{Metode}

Penelitian ini dilakukan di kelurahan kampung nelayan Kecamatan Tungkal Ilir Kabupaten Tanjung Jabung Barat. Jenis data yang digunakan dalam penelitian ini adalah data kuantitatif berdasarkan dimensi waktu, jenis data yang digunakan dalam penelitian ini adalah data cross section. Sumber datanya didapat dari data primer berupa data langsung yang dikumpulkan melalui wawancara dengan responden dan menggunakan alat penelitian atau pedoman wawancara serta observasi yaitu mengamati secara langsung. Untuk mendapatan data yang digunakan dalam penelitian ini digunakan teknik kuesioner. Pengambilan sampel dalam penelitian ini menggunakan metode Proposive Sampling untuk mengetahui populasi yang mana ingin diteliti. Teknik purposive sampling adalah teknik penetuan sampel dengan pertimbangan tertentu (sugiyono,2011). Sampel yang digunakan dalam penelitian ini berjumlah 97 responden.

Pada penelitian ini peneliti mengggunakan metode analisis regresi berganda (multiple regression) karena penelitian ini menggunakan variabel multivariat dengan satu variabel dependen yang bersifat matrik. Metode analisis ini berguna untuk mengetahui seberapa besar pengaruh variabel independen terhadap variabel dependen. Adapun model persamaan regresi yang digunakan dalam penelitian ini adalah sebagai berikut:

$\mathrm{Y}=\mathrm{a}+\mathrm{b} 1 \mathrm{X} 1+\mathrm{b} 2 \mathrm{X} 2+\mathrm{b} 3 \mathrm{X} 3+\mathrm{b} 4 \mathrm{X} 4+\mathrm{e}$

Untuk estimasi koefisien regresi, ditransformasi ke bentuk linear dengan menggunakan logaritma natural (Ln) guna menghitung nilai elastisitas dari masing -masing variabel terhadap variabel terikat ke dalam modal sehingga diperoleh persamaan sebagai berikut:

$\mathrm{Ln} \mathrm{Y}=\mathrm{A}+\mathrm{B} 1 \mathrm{Ln} \mathrm{X} 1+\mathrm{B} 2 \mathrm{Ln} \mathrm{X} 2+\mathrm{B} 3 \mathrm{Ln} \mathrm{X} 3+\mathrm{B} 4 \mathrm{Ln} \mathrm{X} 4+\mathrm{E}$

Dimana : $\mathrm{Y}=$ Pendapatan Nelayan; $\mathrm{X} 1=$ Modal; $\mathrm{X} 2=$ Teknologi; $\mathrm{X} 3=$ Pengalaman Kerja; $\mathrm{X} 4=$ Jarak Tempuh; $\mathrm{a}=$ konstanta; $\mathrm{e}=$ batasan erorr

b1,b2,b3, dan b4 = koefisien

\section{Hasil}

Analisis regresi berganda dalam penelitian ini dilakukan dengan menggunakan bantuan program SPSS Versi 17.0 menghasilkan persamaan regresi sebagai berikut :

$\mathrm{Y}=3,583+0,755 \mathrm{X} 1-0,058 \mathrm{X} 2+0,042 \mathrm{X} 3-0,037 \mathrm{X} 4$

$$
(12,176)(-1,122)(0,581)(-0,739)
$$

$\mathrm{r}=0,811 ; \mathrm{r}^{2}=0,657 ; \mathrm{t}$ tabel $=1,985 ; \mathrm{f}$ hitung $=44,135 ; \mathrm{f}$ tabel $=2,47$

Catatan : angka dalam kurung adalah nilai t hitung parameter

Dari model persamaan regresi liner berganda di atas dapat diketahui bahwa:

1. Nilai konstanta sebesar 3,583 berarti apabila seluruh variabel independen konstanta atau bernilai nol, maka besarnya pendapatan nelayan di kabupaten tanjung jabung barat sebesar 3,583.

2. Nilai koefisien regresi variabel modal (X1) sebesar 0,755 yang bertanda positif. Berarti adanya pengaruh positif modal terhadap pendapatan nelayan, apabila nilai variabel modal meningkat sebesar $1 \%$ maka akan menyebabkan kenaikan pendapatan sebesar 0,782 .

3. Nilai koefisien regresi variabel teknologi (X2) sebesar $-0,058$ yang bertanda negatif. Berarti adanya pengaruh negatif teknologi terhadap pendapatan nelayan, apabila nilai variabel teknologi meningkat sebesar $1 \%$ maka akan menyebabkan penurunan pendapatan sebesar $-0,072$.

4. Nilai koefisien regresi variabel pengalaman kerja (X3) sebesar 0,042 yang bertanda positif. Berarti adanya pengaruh positif pengalaman kerja terhadap pendapatan nelayan, apabila nilai variabel pengalaman kerja meningkat $1 \%$ maka akan menyebabkan kenaikan pendapatan sebesar 0,037. 
5. Nilai koefisien regresi variabel jarak tempuh melaut (X4) sebesar - 0,037 yang bertanda negatif. Berarti adanya pengaruh negatif jarak tempuh melaut terhadap pendapatan nelayan, apabila nilai variabel jarak tempuh melaut meningkat $1 \%$ maka akan menyebabkan penurunan pendapatan sebesar -0,046.

Tabel 1

Coefficient

\begin{tabular}{|c|c|c|c|c|c|c|c|}
\hline \multirow[b]{2}{*}{ Model } & \multicolumn{2}{|c|}{ Unstandardized Coefficients } & \multirow{2}{*}{$\begin{array}{c}\text { Standardized Coefficients } \\
\text { Beta }\end{array}$} & \multirow[b]{2}{*}{$\mathrm{t}$} & \multirow[b]{2}{*}{ Sig. } & \multicolumn{2}{|c|}{ Collinearity Statistics } \\
\hline & B & Std. Error & & & & Tolerance & VIF \\
\hline 1 (constant) & 3.583 & .792 & & 4.523 & .000 & & \\
\hline Ln_X1 & .755 & .062 & .782 & 12.176 & .000 & .902 & 1.109 \\
\hline $\mathrm{Ln}-\mathrm{X} 2$ & -.058 & .052 & -.072 & -1.122 & .265 & .911 & 1.098 \\
\hline Ln_X3 & .042 & .073 & .037 & .581 & .562 & .910 & 1.098 \\
\hline $\mathrm{Ln}^{-} \mathrm{X} 4$ & -.037 & .050 & -.046 & -.739 & .462 & .943 & 1.061 \\
\hline
\end{tabular}

Sumber: data olahan

Berdasarkan tabel 1 diatas, maka dapat diketahui nilai VIF untuk masing-masing variabel penelitian sebagai berikut :

1. Nilai Variance Inflation Factor (VIF) untuk variabel modal sebesar $1,109<10$ dan nilai Tolerance variabel sebesar 0,902 >0,10 sehingga variabel modal dinyatakan tidak terjadi multikolinieritas.

2. Nilai Variance Inflation Factor (VIF) untuk variabel teknologi sebesar 1,098 $<10$ dan nilai Tolerance variabel sebesar 0,911 >0,10, sehingga variabel teknologi dinyatakan tidak terjadi multikolinieritas.

3. Nilai Variance Inflation Factor (VIF) untuk variabel pengalaman kerja sebesar 1,098 < 10 dan nilai Tolerance variabel sebesar 0,910 >0,10, sehingga variabel teknologi dinyatakan tidak terjadi multikolinieritas.

4. Nilai Variance Inflation Factor (VIF) untuk variabel jarak tempuh melaut sebesar 1,061 < 10 dan nilai Tolerance variabel sebesar 0,943>0,10, sehingga variabel teknologi dinyatakan tidak terjadi multikolinieritas.

Hasil output diatas, maka tampak bahwa nilai sig variabel modal (X1) 0,000 hasil tersebut maka tampak bahwa satu variabel ada gejala heteroskedastisitas karena nilai sig $<0,05$. Sedangkan nilai sig variabel teknologi $(\mathrm{X} 2)$ 0,265, pengalaman kerja (X3) 0,562 dan jarak tempuh melaut (X4) 0,462 dari hasil tersebut maka tampak bahwa ketiga variabel tidak ada gejala heteroskedastisitas karena nilai sig $<0,05$.

Tabel 2

Uji Autokorelasi

\begin{tabular}{|c|c|r|r|r|r|}
\hline Model & $\mathrm{R}$ & $\mathrm{R}$ Square & Adjusted R Square & Std. Error of the Estimate & Durbin-Watson \\
\hline 1 & $.811^{\mathrm{a}}$ & .657 & .643 & .16015 & 2.063 \\
\hline
\end{tabular}

Sumber: data olahan

Tabel 3 diatas diketahui nilai DW sebesar 2,063 selanjutnya nilai ini akan dibandingkan dengan nilai tabel signifikan 5\% jumlah sampel $\mathrm{N}=97$ dan jumlah variabel independen $\mathrm{k}=4$, maka diperoleh nilai du 1,753 nilai $\mathrm{Dw}$ 2,063 lebih besar dari batas atas atau (du) yakni 1,753 dan kecil dari $(4-\mathrm{du})$ atau $4-1,753=2,247$, jadi dapat disimpulkan bahwa koefisien bebas dari gangguan autokorelasi.

Tabel 3

Uji Statistik F

\begin{tabular}{|c|c|c|c|c|c|}
\hline Model & Sum of Squares & Df & Mean Square & $\mathrm{F}$ & Sig. \\
\hline 1 Regression & 4.528 & 4 & 1.132 & \multirow[t]{3}{*}{44.135} & \multirow[t]{3}{*}{$.000^{\mathrm{a}}$} \\
\hline Residual & 2.s360 & 92 & .026 & & \\
\hline Total & 6.888 & 96 & & & \\
\hline
\end{tabular}

Sumber: data olahan

Berdasarkan hasil analisis, nilai F-hitung adalah sebesar 44,135 sedangkan nilai F-tabel sebesar 2,47 nilai tersebut menunjukkan bahwa nilai F-hitung > F-tabel pada tingkat kepercayaan 95\%. Hal ini menunjukkan pendapatan nelayan di Kabupaten Tanjung Jabung Barat dipengaruhi secara simultan oleh variabel independen yang ada dalam model. Dengan demikian dugaan bahwa pendapatan nelayan dipengaruhi oleh modal, teknologi, pengalaman kerja dan jarak tempuh melaut dapat diterima. 


\section{Uji Statistik t}

Berdasarkan Tabel 1 dapat dijelaskan bahwa:

a. Variabel modal (X1) mempunyai nilai thitung sebesar 12,176 dan nilai signifikansi untuk variabel modal adalah 0,000 dinyatakan lebih kecil dari taraf $\alpha=0,05(0,000>0,05)$. Hal ini menunjukkan juga dengan nilai thitung $=$ 0,939 dan nilai ttabel dengan tingkat signifikan 5\% $(0,05) \mathrm{df}=94$ adalah 1,985, sehingga thitung < ttabel $(12,176$ $<1,985)$. Dari hasil tersebut sehingga dapat disimpulkan bahwa variabel modal mempunyai pengaruh positif dan signifikan terhadap pendapatan nelayan.

b. Variabel teknologi (X2) mempunyai nilai thitung sebesar - 1,122 dan nilai signifikansi untuk variabel teknologi adalah 0,265 dinyatakan lebih besar dari taraf $\alpha=0,05(0,265<0,05)$. Hal ini menunjukkan juga dengan nilai thitung $=-1,122$ dan nilai ttabel dengan tingkat signifikan $5 \%(0,05) \mathrm{df}=94$ adalah 1.985 , sehingga thitung > ttabel $(-1,122<1,985)$. Dari hasil tersebut sehingga dapat disimpulkan bahwa variabel teknologi mempunyai pengaruh negatif dan tidak signifikan terhadap pendapatan nelayan.

c. Variabel pengalaman kerja (X3) mempunyai nilai thitung sebesar 0,581 dan nilai signifikansi untuk variabel pengalaman kerja adalah 0,562 dinyatakan lebih besar dari taraf $\alpha=0,05(0,562>0,05)$. Hal ini menunjukkan juga dengan nilai thitung $=0,581$ dan nilai ttabel dengan tingkat signifikan $5 \%(0,05) \mathrm{df}=94$ adalah 1.985 , sehingga thitung < ttabel $(0,581<1,985)$. Dari hasil tersebut sehingga dapat disimpulkan bahwa variabel pengalaman kerja mempunyai pengaruh positif dan signifikan terhadap pendapatan nelayan.

d. Variabel jarak tempuh melaut (X4) mempunyai nilai thitung sebesar - 0,739 dan nilai signifikansi untuk variabel jarak tempuh melaut adalah 0,462 dinyatakan lebih besar dari taraf $\alpha=0,05(0,462>0,05)$. Hal ini menunjukkan juga dengan nilai thitung $=-0,739$ dan nilai ttabel dengan tingkat signifikan $5 \%(0,05) \mathrm{df}=94$ adalah 1.985 , sehingga thitung < ttabel $(-0,739<1,985)$. Dari hasil tersebut sehingga dapat disimpulkan bahwa variabel jarak tempuh melaut mempunyai pengaruh negatif dan tidak signifikan terhadap pendapatan nelayan.

Koefisien determinasi pada Tabel 2 menunjukkan seberapa besar variabel terikat yang dapat dijelaskan oleh variabel bebas. Berdasarkan hasil analisis regresi linier berganda diperoleh nilai koefisien determinasi (R2) sebesar 0,811 menunjukkan bahwa $81,1 \%$ variabel terikat mampu dijelaskan oleh variabel bebas yang dimasukkan ke dalam model ( modal, teknologi, pengalaman kerja, dan jarak tempuh melaut), sedangkan sisanya sebesar 18,9\% dipengaruhi oleh faktor lain yang tidak dimasukkan dalam model. Uji koefisien korelasi dimaksudkan untuk mengetahui seberapa besar keterkaitan hubungan antara variabel independen terhadap variabel dependen. Nilai $\mathrm{R}$ akan berada pada $0<\mathrm{r}<$ 1, atau semakin mendekati 0 (nol) maka semakin lemah jika mendekati 1 (satu) semakin kuat. Perhitungan statistik diperoleh nilai koefisien korelasi $\mathrm{R}$ sebesar 0,811 , artinya terdapat hubungan yang cukup kuat antara variabel bebas (modal, teknologi, pengalaman kerja dan jarak tempuh melaut) dengan variabel terikat (pendapatan nelayan) sangat kuat.

\section{Pembahasan \\ Pengaruh Modal (X1) Terhadap Pendapatan Nelayan}

Berdasarkan hasil penelitian terdapat pengaruh antara modal (X1) terhadap pendapatan nelayan (Y) dengan nilai signifikansi pada variabel modal sebesar $0,000<0,05$, maka menunjukkan adanya pengaruh signifikan dari variabel modal terhadap pendapatan nelayan. Penelitian ini menemukan bahwa secara parsial modal mempengaruhi pendapatan nelayan secara negatif. Artinya semakin banyak jumlah modal akan meningkatkan pendapatan nelayan di kabupaten tanjung jabung barat. Artinya meningkatnya modal disebabkan oleh meningkatnya pendapatan nelayan sehingga nelayan mempunyai kemampuan yang tinggi untuk menambah persediaan bahan bakar dalam melaut, persediaan es balok, mengganti mesin rusak dan memperbaiki kapal sehingga layak untuk dibawa melaut serta memiliki alat tangkap yang lebih tinggi teknologinya sehingga nelayan tersebut dapat meningkatkan hasil produksi ikan laut tangkapan nelayan, yang pada gilirannya akan dapat meningkatkan pendapatan nelayan di kabupaten tanjung jabung barat. Temuan penelitian ini konsisten dengan teori Mankiw (2009) yang terkait hubungan antara modal dan produksi, dalam kegiatan produksi membutuhkan adanya faktor produksi salah satunya adalah modal.bila modal meningkat maka produksi juga meningkat. Hal ini menunjukkan kepada kita bahwa dalam peningkatan output harus didiringi dengan peningkatan input, salah satu input yang dibutuhkan dalam proses produksi merupakan modal. Dengan demikian temuan penelitian ini membuktikan bahwa peningkatan dari modal nelayan memberikan pengaruh negatif dapat meningkatkan produksi ikan laut dan meningkatkan pendapatan nelayan. Hasil penelitian ini sesuai dengan penelitian yang dilakukan oleh Surano (2008) tentang analisis faktor-faktor yang mempangruhi pendapatn nelayan di Kabupaten Langkat diperoleh hasil terdapat pengaruh modal dengan pendapatan nelayan.

\section{Pengaruh Teknologi (X2) Terhadap Pendapatan Nelayan}

Berdasarkan hasil penelitian tidak terdapat pengaruh antara teknologi (X2) terhadap pendapatan nelayan (Y) dengan nilai signifikansi pada variabel modal sebesar $0,265>0,05$, maka menunjukkan tidak adanya pengaruh 
signifikan dari variabel teknologi terhadap pendapatan nelayan. Penggunaan dari teknologi dijelaskan dalam teori David Ricardo bahwa kemajuan teknologi akan cenderung untuk meningkatkan produktivitas. Penggunaan dari teknologi akan memberikan kemudahan kepada seseorang untuk melakukan suatu kegiatan produksi. Jadi penggunaan teknologi modern selain memberikan kemudahan akan mampu meningkatkan produktivitas dan akan mampu memberikan sumbangan terhadap pendapatan. Hal ini didukung dengan pernyataan bahwa ketergantungan nelayan terhadap teknologi penangkapan sangat tinggi, karena daerah penangkapan yang bersifat pindah-pindah sehingga membutuhkan teknologi yang canggih untuk melakukan kegiatan produksi. Penelitian ini tidak sejalan dengan penelitian yang dilakukan oleh Irmayanti (2015), menyatakan bahwa teknologi berpengaruh positif terhadap pendapatan para nelayan, karena semakin canggih alat tangkap yang digunakan oleh para nelayan maka akan meningkatkan produktivitas hasil tangkapan.

\section{Pengaruh Pengalaman Kerja (X3) Terhadap Pendapatan Nelayan}

Berdasarkan hasil penelitian tidak terdapat pengaruh antara pengalaman kerja (X3) terhadap pendapatan nelayan (Y) dengan nilai signifikansi pada variabel pengalaman kerja sebesar 0,562 >0,05, maka menunjukkan tidak adanya pengaruh signifikan dari variabel pengalaman kerja terhadap pendapatan nelayan. Pengalaman kerja secara teori berpengaruh terhadap pendapatan nelayan, hal ini tidak sejalan dengan nelayan di kabupaten tanjung jabung barat karena apabila pengalaman kerja yang sangat lama dalam menangkap ikan, maka pendapatan nelayan menurun. Pengalaman memang sangat dibutuhkan disetiap pekerjaan.Pengalaman dibutuhkan untuk manajemen produksi nelayan.Mencari ikan membutuhkan waktu, peralatan, lokasi ikan, dan umpan ikan yang tepat.Hal tersebut dapat diketahui oleh nelayan berdasarkan berjalannya waktu.Semakin paham seorang nelayan dengan kondisi laut dan karakteristik ikan dapat mempermudah nelayan tersebut menangkap ikan.Penggunaan alat yang masih sederhana memaksa nelayan menggunakan pengalaman untuk menangkap ikan, semakin lama pengalaman maka semakin peka nelayan terhadap posisi ikan sehingga memudahkan nelayan untuk menangkap ikan. Hasil penelitian ini tidak sesuai dengan penelitian yang dilakukan oleh Badrul Jamal (2014) tentang analisis faktor-faktor yang mempengaruhi pendapatan nelayan, (studi nelayan pesisir Desa Klampis Kecamatan Klampis Kabupaten Bangkalan), yang menyatakan bahwa variabel pengalaman kerja secara parsial berpengaruh signifikan terhadap pendapatan nelayan di Desa Klampis.

\section{Pengaruh Jarak Tempuh Melaut (X4) Terhadap Pendapatan Nelayan}

Berdasarkan hasil penelitian jarak tempuh melaut menunjukkan bahwa jarak tempuh melaut tidak berpengaruh signifikan $(0,462>0,05)$, Pendapatan nelayan di Kabupaten tanjung jabung barat. Hal ini menunjukkan semakin jauh Jarah Tempuh Melaut (jauh dari daratan) maka semakin besar pula hasil tangkapan ikan sehingga akan menambah nilai penghasilan para nelayan dan tentunya akan meningkatkan pendapatandan sebaliknya, semakin rendah (semakin dekat) Jarak Tempuh Melaut maka hasil tangkapan ikan semakin kecil dan akan mengurangi pendapatan nelayan tersebut. Pada umumnya penangkapan ikan lepas pantai yang dilakukan dalam waktu yang lebih lama dan lebih jauh dari daerah sasaran tangkapan ikan mempunyai nilai lebih banyak kemungkinan memperoleh hasil tangkapan (produksi) yang lebih banyak dan tentu memberikan pendapatan lebih besar dibandingkan dengan penangkapan ikan yang dekat pantai. Penelitian ini tidak sesuai dengan penelitian yang dilakukan oleh Ida Ayu dkk (2014) tentang analisis faktor-faktor yang mempengaruhi pendapatan nelayan buruh di sepanjang Muaro Sungai Ijo Gading Kabupaten Jembara.yang menyatakan bahwa variabel jarak tempuh melaut berpengaruh dominan terhadap pendapatan nelayan buruh di Kawasan Muara Sungai Ijo Gading Kabupaten jembara.

\section{Simpulan}

Berdasarkan tujuan penelitian dan hasil penelitian yang telah dilakukan maka dapat diambil kesimpulan sebagai berikut:

a. Faktor-faktor yang mempengaruhi pendapatan nelayan tradisional di kabupaten tanjung jabung barat yaitu : modal, teknologi, pengalaman kerja dan jarak tempuh melaut.

b. Berdasarkan hasil uji secara simultan bahwa variabel modal, teknologi, pengalaman kerja dan jarak tempuh melaut secara bersama-sama memiliki pengaruh terhadap pendapatan nelayan tradisional di kabupaten tanjung jabung barat karena F hitung $(44,135)>\mathrm{F}$ tabel $(2,47)$ maka menerima Ha dan Ho di tolak. Hal ini menunjukkan bahwa secara bersama-sama variabel bebas berpengaruh terhadap pendapatan nelayan tradisional di kabupaten tanjung jabung barat.

c. Berdasarkan hasil uji secara parsial bahwa modal memiliki pengaruh positif dan signifikan terhadap pendapatan nelayan di kabupaten tanjung jabung barat. Sedangkan teknologi dan jarak tempuh melaut memiliki pengaruh negatif tetapi tidak signifikan terhadap pendapatan nelayan tradisional di kabupaten tanjung jabung barat. Dan pengalaman kerja memiliki pengaruh positif tetapi tidak signifikan terhadap pendapatan nelayan tradisional di kabupaten tanjung jabung barat. 


\section{Daftar Pustaka}

Adhar., (2011). Analisis Faktor-Faktor Yang Mempengaruhi Tingkat Pendapatan Usaha Nelayan Di Kabupaten Bone, Skripsi, Universitas Hasanuddin

Agung gunanto Yusuf Edy., (2011). Analisis Kemiskinan Dan Pendapatan Keluarga Nelayan Kasus Di Kecamatan Wedung Kabupaten Demak, Jawa Tengah, Indonesia

Ardhianto, Rofiza., (2015). Pengaruh Pendapatan Nelayan Perahu Rakit Terhadap Pola Konsumsi Warga Desa Surodadi Kecamatan Sayung Kabupaten Demak

Afiahartani, Nurul, (2017). Pengaruh Modal Kerja, Tenaga Kerja Dan Jarak Tempuh Melaut Terhadap Pendapatan Nelayan Di Kelurahan Lappa Kecamatan Sinjai Utara Kabupaten Sinjai

Dahen, Lovelly Dwinda. (2016). Analisis Pendapatan Nelayan Pemilik Payang Di Kecamatan Koto Tangah Kota Padang. Journal Of Economic And Economic Education, Vol 5 No.1 (47-57).

Jamal, Badrul.(2015). Analisis Faktor-Faktor Yang Mempengaruhi Pendapatan Nelayan (Studi Nelayan Pesisir Desa Klampis Kecamatan Klampis Kabupaten Bangkalan). Fakultas Ekonomi Dan Bisnis Universitas Brawijaya Vol 2

Joesron, Tati Suhartati; Fathorrazi, M. (2011). Teori Ekonomi Mikro, Edisi Pertama. Yogyakarta; Graha Ilmu.

Kurniasari Atika Desi., (2016). Pengaruh Pendapatan, Dependency Ratio Dan Tingkat Pendidikan Nelayan Terhadap Pola Konsumsi Rumah Tangga Nelayan Di Pesisir Pantai Depok Yogyakarta.

Lamia, Karof Alfentino, (2013). Faktor-Faktor Yang Mempengaruhi Tingkat Pendapatan Nelayan Kecamatan Tumpaan, Kabupaten Minahasa Selatan. Jurnal EMBA Fakultas Ekonomi Dan Bisnis Vol 1 No 4

Nirmawati., (2018). Faktor-Faktor Yang Mempengaruhi Tingkat Pendapatan Nelayan Di Kecamatan pajjukukang Kabupaten Bantaeng

Nugroho Restu Vicky., (2017). Analisis Faktor - Faktor Yang Mempengaruhi Hasil Pendapatan Nelayan Di Desa Bendar Kecamatan Juwana Kabupaten Pati.

Rahmatsyah, Teuku., (2015). Analisis Beberapa Faktor Yang Mempengauhi Tingkat Pendapatan Nelayan Pemilik Kapal Di Kota Lhokseumaw.

Rahardja, Prathama, (2008). Pengantar Ilmu Ekonomi (Mikroekonomi \& Makroekonomi), Edisi Ketiga. Jakarta: lembaga penerbit fakultas ekonomi universitas Indonesia.

Roxes, Manuel, (2017). Analisis Faktor-Faktor Yang Mempengaruhi Pendapatan Nelayan Tradisioanl Di Kelurahan Belawan Bahagia Kecamatan Medan Belawan Kota Medan.

Rahman, Miftakhur, (2017).Faktor-Faktor Yang Mempengaruhi Pendapatan Nelayan Cantrang (Studi Kasus: TPI Bajomulyo Kec. Juwana Jawa Tengah).

Rahman, Rosyidah, (dkk) (2016). Pengaruhi Modal, Tenaga Kerja dan Jarak Tempuh Terhadap Pendapatan Nelayan di Desa Pulau Kaung Kecamatan Bluer Tahun 2016. Jurnal Ekonomi Dan Bisnis Vol 14 No 1.

Ridha, Ahmad. (2017).Analisis Faktor-Faktor Yang Mempengaruhi Pendapatan Nelayan Di Kecamatan Idi Rayeuk. Jurnal Samudra Ekonomi Dan Bisnis Vol 8 No 1.

Syahma Asmita., (2016).Analisis Faktor-Faktor Yang Mempengaruhi Pendapatan Nelayan Tangkap Di Desa Galesong Kota Kecamatan Galesong Kabupaten Takalar

Sukirno, Sadono, (2014). Mikoekonomi Teori Pengantar, edisi ketiga. Jakarta; Rajawali Pers.

Sujarno, (2008).Analisis Faktor-Fakror Yang Mempengaruhi Pendapatan Nelayan Di Kabupaten Langakt. Universitas Sumatera Utara 4(1): 1-117.

Sastrawidjaya. (dkk) (2001). Nelayan Nusantara. Pusat Riset Pengolahan Produk Sosial Ekonomi Kelautan Dan Perikanan. Jakarta.

Sulastri, (dkk) (2014).Analisis Faktor-Faktor Yang Mempengaruhi Pendapatan Nelayan Di Kabupaten Aceh Besar. Jurnal Ilmu Ekonomi Vol 1 No 3. 